\title{
NMR Spectroscopy, Hammett Correlations and Biological Activity of Some Schiff Bases Derived from Piperonal
}

\author{
Aurea Echevarria ${ }^{\mathrm{a}}$, Maria da Graça Nascimento ${ }^{\mathrm{b}}$, Vanilde Gerônimo ${ }^{\mathrm{b}}$, \\ Joseph Miller ${ }^{\mathrm{c}}$, and Astréa Giesbrecht ${ }^{\mathrm{d}}$ \\ a Departamento de Química, Universidade Federal Rural do Rio de Janeiro, \\ 23851-970 Itaguai - RJ, Brazil; \\ ${ }^{\mathrm{b}}$ Departamento de Química, Universidade Federal de Santa Catarina, \\ 88040-900 Florianópolis - SC, Brazil; \\ ${ }^{\mathrm{c}}$ LTF, Universidade Federal da Paraiba, 58051-970 João Pessoa - PB, Brazil;: \\ d Instituto de Ciências Biomédicas, Universidade de São Paulo, \\ 05508-000 São Paulo - SP, Brazil
}

Uma série de Bases de Schiff foi sintetizada através da reação de condensação do piperonal (3,4-metilenodioxibenzaldeido) com as correspondentes aminas primárias aromáticas. Seus espectros de RMN de ${ }^{1} \mathrm{H}$ e ${ }^{13} \mathrm{C}$ foram obtidos e estudou-se as correlações de Hammett envolvendo os deslocamentos químicos e as constantes dos substituíntes $\left(\sigma_{\mathrm{p}}, \sigma_{\mathrm{R}}\right.$ e $\left.\sigma_{\mathrm{I}}\right)$. Observou-se correlações lineares e bilineares significativas para o carbono imínico $(C-\alpha)$ e C-1', indicando maior contribuição do efeito de ressonância do substituinte sobre os deslocamentos químicos. Os assinalamentos dos C-4' apresentaram-se bem alterados pelos efeitos dos substituíntes, especialmente pelos halogênios, na direção esperada. A série de Bases de Schiff foi ensaiada contra microorganismos, sendo que apresentou atividade significativa frente a fungos filamentosos, especialmente o Epidermophyton floccosum. Não foram observadas correlações significativas entre a atividade biológica e os efeitos eletrônicos.

A series of eleven Schiff Bases have been synthesized. They were obtained by condensation of piperonal (3,4-methylenedioxybenzaldehyde) with the corresponding aromatic primary amines. Their ${ }^{1} \mathrm{H}$ and ${ }^{13} \mathrm{C}$-NMR spectra have been obtained and the Hammett correlations including chemical shifts and the subsitutent constants $\left(\sigma_{\mathrm{p}}, \sigma_{\mathrm{R}}\right.$ e $\left.\sigma_{\mathrm{I}}\right)$ were studied. Linear and bilinear significant correlations were observed for iminic carbon $(\mathrm{C}-\alpha)$ and C-1', showing a more significant ressonance effect on chemical shifts. The chemical shifts for C-4' were highly affected by substituent effects, especially for halogens in the expected direction. Their biological activity against microorganisms has also been measured and significant activity was showed against Epidermophyton floccosum. The biological activity did not give a reasonable relationship with electronic effects.

Keywords: Hammett NMR correlations, piperonal

\section{Introduction}

Carbonyl, nitrile and imidoyl groups are classed as heteropolar unsaturated functions. Much work has been carried out with carbonyl compounds, and the chemistry of nitrile compounds is also well explored. There are many different types of compounds which contain the imidoyl function and in total the body of work on this subject is quite substantial ${ }^{1}$. We have, for a long time, maintained interest in compounds containing $>\mathrm{C}=\mathrm{N}-\mathrm{X}$ functions and have included some comparisons of $>\mathrm{C}=\mathrm{O} ;>\mathrm{C}=\mathrm{N}$ and $>\mathrm{C}=\mathrm{N}-\mathrm{X}$ functions $^{2-8}$. Later, we reported studies on NMR spectroscopy $^{9}$ and biological activity of some $>\mathrm{C}=\mathrm{N}-\mathrm{X}$ compounds ${ }^{10,11}$. We have also considered saturation of internal resonance effects in guanidines ${ }^{12}$. Studies of Schiff Bases 
have also included 4- and 4'-substituted-N-benzylidenanilines $^{9,10}$ and N-benzylidene-3,3-diphenyl-propylamines ${ }^{13}$ and in both series, ${ }^{1} \mathrm{H}$ and ${ }^{13} \mathrm{C}$-NMR spectra were analysed. Studies of infra-red and ultra-violet spectra for 3,3diphenylpropylamine derivatives were also carried out together with preliminary tests of their biological activities.

The interesting results obtained with this series of Schiff Bases, led us to synthesize and study a series of eleven N-benzylidene-4'-substituted-anilines in which the benzylidene moiety was fixed as 3,4-methylenedioxybenzylidene. The choice of piperonal for the aldehyde moiety in these preparations stemmed from the fact that many compounds containing the 3,4-methylenedioxy group have some biological activity ${ }^{14,15}$. The ${ }^{13}$ C-NMR spectroscopy and Hammett correlations were investigated for Schiff Bases derived from piperonal.

\section{Materials and Methods}

\section{Preparation of the Schiff bases}

The Schiff bases were prepared by condensation of piperonal with the corresponding amines following a general method of preparation ${ }^{16}$. The products were recrystallized from analytical grade ethanol to constant melting point. Their purity was confirmed by elemental analysis, and UV and IR spectroscopy. Details of their physical properties are given in Table 1.

\section{NMR Data}

The ${ }^{1} \mathrm{H}$ and ${ }^{13} \mathrm{C}$-NMR spectra were determined at $30^{\circ} \mathrm{C}$ on a Varian XL-100 spectrometer $\left({ }^{1} \mathrm{H}\right.$ : $100 \mathrm{MHz}$ and ${ }^{13} \mathrm{C}$ : 25.2 MHz), for ca. $0.3 \mathrm{M}$ and saturated solutions in $\mathrm{CDCl}_{3}$ or DMSO-d 6 , respectively, with TMS as internal standard.
The ${ }^{1} \mathrm{H}$ and ${ }^{13} \mathrm{C}-\mathrm{NMR}$ spectral data used for Hammett correlations are shown in Table 2.

\section{Biological assays}

Assays with bacteria and yeasts were performed by the agar well diffusion method (cavity-plate), using trypticase soy agar and Sabourand-dextrose agar, respectively. The concentration of samples ranged from 2 to $4 \mathrm{mg} / \mathrm{mL}$ in pure DMSO for bacteria and $\mathrm{DMSO} / \mathrm{H}_{2} \mathrm{O}(1: 1 \mathrm{v} / \mathrm{v})$ for yeasts.

The bacteria used were: Bacillus cereus, Staphylococcus epidermides and Escherischia coli. The yeasts used were: Candida albicans, Candida tropicalis, Cryptococcus neoformans and Torulopsis glabrata. The cultures are place on the Micoteca of Departamento de Microbiologia do Instituto of Ciências Biomédicas of Universidade de São Paulo.

Assays with filamentous fungi involved the utilization of two-fold serial dilution in Sabourand-dextrose liquid medium. The concentration of samples ranged from 62.5 to $500 \mu \mathrm{g} / \mathrm{mL}$. The test compounds were dissolved in DMSO $(0.1 \mathrm{~mL})$ and the solution was added to sterile Sabouranddextrose agar solution. The maximum concentration of organic solvent was $2.5 \%$.

The results are expressed in MIC (minimal inhibitory concentration). The fungi used were: Microsporum canis, Microsporum gypseum, Trichophyton rubrum and Epidermophyton floccosum. Solvent blanks were run against each test organism, in all assays. The results of the fungi assays are shown in Table 3.

Table 1. Physical and spectral data for Schiff Bases derived from piperonal and $p$-substituted anilines.

\begin{tabular}{|c|c|c|c|c|c|c|c|c|c|}
\hline \multirow[t]{2}{*}{$X$} & \multirow{2}{*}{$\begin{array}{c}\text { Yield } \\
(\%)\end{array}$} & \multirow{2}{*}{$\begin{array}{l}\text { M.p. } \\
\left({ }^{\circ} \mathrm{C}\right)\end{array}$} & \multirow{2}{*}{$\begin{array}{c}\lambda_{\max }{ }^{a} \\
(\mathrm{~nm})\end{array}$} & \multirow[t]{2}{*}{$\log \varepsilon_{\max }$} & \multirow{2}{*}{$\begin{array}{c}v \mathrm{C}=\mathrm{N}^{\mathrm{b}} \\
\left(\mathrm{cm}^{-1}\right)\end{array}$} & \multirow{2}{*}{$\begin{array}{c}\text { Molecular } \\
\text { Formula }\end{array}$} & \multicolumn{3}{|c|}{ Microanalyses (\%), Found (required) } \\
\hline & & & & & & & $\mathrm{H}$ & $\mathrm{C}$ & $\mathrm{N}$ \\
\hline $\mathrm{OCH}_{3}$ & 73.3 & $119-121$ & $328 ; 231 ; 212$ & $3.34 ; 3.16 ; 3.13$ & 1625 & $\mathrm{C}_{15} \mathrm{H}_{13} \mathrm{O}_{3} \mathrm{~N}$ & 71.07 (70.59) & $5.10(5.10)$ & $5.49(5.27)$ \\
\hline $\mathrm{OC}_{2} \mathrm{H}_{5}$ & 85.3 & $102-105$ & $337 ; 229 ; 212$ & $3.27 ; 3.28 ; 3.12$ & 1630 & $\mathrm{C}_{16} \mathrm{H}_{15} \mathrm{O}_{3} \mathrm{~N}$ & 71.09 (71.37) & $5.47(5.57)$ & $6.43(6.20)$ \\
\hline $\mathrm{CH}_{3}$ & 99.2 & $98-99$ & $328 ; 230 ; 212$ & $3.28 ; 3.21 ; 3.13$ & 1625 & $\mathrm{C}_{15} \mathrm{H}_{13} \mathrm{O}_{2} \mathrm{~N}$ & $73.78(73.31)$ & $5.40(4.40)$ & $5.78(5.86)$ \\
\hline $\mathrm{C}_{2} \mathrm{H}_{5}$ & 66.3 & $55-57$ & $329 ; 229 ; 212$ & $3.23 ; 3.28 ; 3.09$ & 1620 & $\mathrm{C}_{16} \mathrm{H}_{15} \mathrm{O}_{2} \mathrm{~N}$ & $76.09(75.89)$ & $5.54(5.93)$ & $5.51(5.54)$ \\
\hline $\mathrm{H}$ & 81.1 & $68-70$ & $323 ; 228 ; 211$ & $3.20 ; 3.26 ; 3.07$ & 1625 & $\mathrm{C}_{14} \mathrm{H}_{11} \mathrm{O}_{2} \mathrm{~N}$ & $75.38(74.67)$ & $4.94(4.89)$ & $6.67(6.23)$ \\
\hline $\mathrm{Cl}$ & 45.5 & $80-82$ & $329 ; 232 ; 212$ & $3.29 ; 3.28 ; 3.12$ & 1620 & $\mathrm{C}_{14} \mathrm{H}_{10} \mathrm{O}_{2} \mathrm{NCl}$ & $64.33(64.74)$ & $3.86(3.85)$ & $5.67(5.39)$ \\
\hline $\mathrm{Br}$ & 68.6 & $108-110$ & $330 ; 233 ; 212$ & $3.29 ; 3.30 ; 3.13$ & 1620 & $\mathrm{C}_{14} \mathrm{H}_{10} \mathrm{O}_{2} \mathrm{NBr}$ & $55.49(55.44)$ & $3.30)$ & $4.51(4.62)$ \\
\hline I & 70.9 & $129-131$ & $330 ; 233 ; 212$ & $3.20 ; 3.30 ; 3.13$ & 1620 & $\mathrm{C}_{14} \mathrm{H}_{10} \mathrm{O}_{2} \mathrm{NI}$ & $47.76(47.86)$ & $2.88(2.85)$ & $3.86(3.98)$ \\
\hline $\mathrm{COOH}$ & 47.8 & $165-166$ & $295 ; 276 ; 212$ & $3.18 ; 3.18 ; 3.16$ & 1645 & $\mathrm{C}_{15} \mathrm{H}_{11} \mathrm{O}_{4} \mathrm{~N}$ & $66.79(66.90)$ & $4.27(4.13)$ & $5.04(5.20)$ \\
\hline $\mathrm{SO}_{3}^{-} \mathrm{Na}^{+}$ & 53.2 & 250 & $330 ; 238 ; 208$ & $4.18 ; 4.17 ; 4.20$ & 1625 & $\mathrm{C}_{14} \mathrm{H}_{10} \mathrm{O}_{5} \mathrm{NSNa}$ & $51.03(51.06)$ & $3.14(3.04)$ & $4.20(4.25)$ \\
\hline $\mathrm{NO}_{2}$ & 83.3 & 198 & $350 ; 218$ & $4.11 ; 3.95$ & 1630 & $\mathrm{C}_{14} \mathrm{H}_{10} \mathrm{O}_{4} \mathrm{~N}_{2}$ & $62.98(63.22)$ & $3.83(3.71)$ & $10.05(10.40)$ \\
\hline
\end{tabular}

${ }^{\mathrm{a}}$ The UV spectra were determined in absolute ethanol at $25^{\circ} \mathrm{C}$ in the range of concentration of (5-10) $\mathrm{x} 10^{-5} \mathrm{M}$.

${ }^{b}$ The values of $v_{C}=\mathrm{N}$ were measured in $\mathrm{cm}^{-1}$ in $\mathrm{KBr}$ pellets. 


\section{Results and Discussion}

Eleven 3,4-methylenedioxybenzylidene-4'-substituted-anilines have been studied in this work. For a discussion of the ${ }^{1} \mathrm{H}$ and ${ }^{13} \mathrm{C}$-NMR spectra it is convenient to show the numbering used for these compounds, viz,

Table 1 shows the ${ }^{1} \mathrm{H}-\mathrm{NMR}$ chemical shifts of the methine protons (joined to $\mathrm{C}-\alpha$ ), the ${ }^{13} \mathrm{C}-\mathrm{NMR}$ chemical shifts of C-1, C- $\alpha, C-1$ ' and C-4', the values of the Hammett

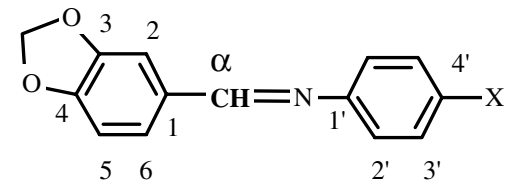

substituent constants $\left(\sigma_{p}\right), \sigma_{\mathrm{R}}$ and $\sigma_{\mathrm{I}}$ values for resonance and inductive constants of the substituents, respectively.

A plot of the ${ }^{1} \mathrm{H}-\mathrm{NMR}$ chemical shifts of the methine protons does not give a reasonable Hammett correlation, whereas there is such a correlation with the methine carbon. Thus, it appears that the ${ }^{13} \mathrm{C}$-NMR shifts are essentially dependent on the perturbation of the aldimine $\pi$-bond. The extension of the effect to the methine protons is essentially a second order effect and we suggest that this accounts for the inadequate correlation.

Substituent effects $(\mathrm{X})$ on ${ }^{13} \mathrm{C}-\mathrm{NMR}$ : (i) on C-1: The values are quite independent of the 4'-substituent. The chemical shifts do not give a reasonable Hammett correlation. This situation is similar to that observed for the ${ }^{1} \mathrm{H}$

Table 2. Chemical shifts ${ }^{\mathrm{a}}\left(\delta \mathrm{H}, \delta \mathrm{C}\right.$ in ppm), Hammett substituent constants ${ }^{\mathrm{b}}\left(\sigma_{\mathrm{p}}\right)$ and dual parameters ${ }^{\mathrm{b}}\left(\sigma_{\mathrm{I}}\right.$ and $\left.\sigma_{\mathrm{R}}\right)$ for substituted Schiff bases derived from piperonal.

\begin{tabular}{lcccccccccc}
\hline $\mathrm{X}$ & $\delta \mathrm{H}$ & $\delta \mathrm{C}-\alpha$ & $\delta \mathrm{C}-1$ & $\delta \mathrm{C}-1$, & $\delta \mathrm{C}-2$, & $\delta \mathrm{C}-3$, & $\delta \mathrm{C}-4$, & $\sigma_{\mathrm{p}}$, & $\sigma_{\mathrm{I}}$ & $\sigma_{\mathrm{R}}$ \\
\hline $\mathrm{OCH}_{3}$ & 8.35 & 157.04 & 131.41 & 144.77 & 121.80 & 114.10 & 157.94 & -0.27 & 0.26 & -0.51 \\
$\mathrm{OC}_{2} \mathrm{H}_{5}$ & 8.38 & 157.07 & 131.37 & 144.67 & 121.07 & 114.74 & 157.31 & -0.24 & 0.22 & -0.44 \\
$\mathrm{CH}_{3}$ & 8.31 & 158.22 & 131.16 & 149.22 & 120.90 & 128.44 & 135.23 & -0.17 & -0.04 & -0.13 \\
$\mathrm{C}_{2} \mathrm{H}_{5}$ & 8.33 & 158.32 & 131.41 & 148.19 & 119.40 & 127.48 & 141.67 & -0.15 & -0.05 & -0.10 \\
$\mathrm{H}$ & 8.25 & 159.04 & 131.03 & 151.82 & 120.60 & 128.73 & 125.48 & 0.00 & 0.00 & 0.00 \\
$\mathrm{Cl}$ & 8.27 & 159.42 & 130.93 & 150.49 & 121.82 & 128.56 & 130.74 & 0.23 & 0.41 & -0.15 \\
$\mathrm{Br}$ & 8.28 & 159.42 & 130.78 & 150.53 & 122.34 & 131.68 & 118.83 & 0.23 & 0.44 & -0.17 \\
$\mathrm{I}$ & 8.27 & 159.42 & 130.53 & 151.23 & 123.13 & 138.27 & 89.71 & 0.18 & 0.40 & -0.19 \\
$\mathrm{COOH}$ & 8.53 & 166.84 & 129.07 & 160.98 & 121.31 & 129.36 & 131.02 & 0.45 & 0.33 & 0.15 \\
$\mathrm{SO}_{3}{ }^{-N a}{ }^{+}$ & 8.45 & 162.34 & 129.54 & 158.77 & 120.16 & 128.54 & 143.81 & 0.09 & $0.15^{\mathrm{c}}$ & $0.33^{\mathrm{c}}$ \\
$\mathrm{NO}_{2}$ & 8.68 & 169.69 & 131.90 & 163.64 & 121.78 & 124.18 & 147.02 & 0.78 & 0.67 & 0.16 \\
\hline
\end{tabular}

${ }^{\mathrm{a}}$ Compounds with $\mathrm{X}=\mathrm{COOH}, \mathrm{SO}_{3} \mathrm{Na}^{+}$and $\mathrm{NO}_{2}$ were recorded in DMSO-d 6 and the others in $\mathrm{CDCl}_{3} ;{ }^{\mathrm{b}}$ Ref. $17 ;{ }^{\mathrm{c}} \mathrm{Ref} 18$.

Table 3. Minimal inhibitory concentration for the biological activity of the Schiff Bases with filamentous fungi.

\begin{tabular}{lcccccccc}
\hline $\mathrm{X}$ & \multicolumn{2}{c}{ Microsporumcanis } & \multicolumn{2}{c}{ Microsporumgypseum } & \multicolumn{2}{c}{ Trichophytonrubrum } & \multicolumn{2}{c}{ Epidermophytonffloccosum } \\
\cline { 2 - 9 } & $(\mu \mathrm{g} / \mathrm{mL})$ & $\mathrm{mM}$ & $(\mu \mathrm{g} / \mathrm{mL})$ & $\mathrm{mM}$ & $(\mu \mathrm{g} / \mathrm{mL})$ & $\mathrm{mM}$ & $(\mu \mathrm{g} / \mathrm{mL})$ & $\mathrm{mM}$ \\
\hline $\mathrm{OCH}_{3}$ & 500 & 1.96 & 500 & 1.96 & 250 & 0.98 & 62.5 & 0.24 \\
$\mathrm{OCH}_{2} \mathrm{H}_{5}$ & $\mathrm{NI}$ & $\mathrm{NI}$ & $\mathrm{NI}$ & $\mathrm{NI}$ & $\mathrm{NI}$ & $\mathrm{NI}$ & 250 & 0.93 \\
$\mathrm{CH}_{3}$ & 500 & 2.09 & 500 & 2.09 & 500 & 2.09 & 250 & 1.04 \\
$\mathrm{C}_{2} \mathrm{H}_{5}$ & 500 & 1.97 & 500 & 1.97 & 250 & 0.97 & 62.5 & 0.25 \\
$\mathrm{H}$ & 250 & 1.11 & 500 & 2.22 & 500 & 2.22 & 250 & 1.11 \\
$\mathrm{Cl}$ & 500 & 1.93 & 500 & 1.93 & 250 & 0.96 & 62.5 & 0.24 \\
$\mathrm{Br}$ & 500 & 1.64 & NI & NI & 250 & 0.82 & 62.5 & 0.20 \\
$\mathrm{I}$ & 500 & 1.42 & NI & NI & NI & NI & 250 & 0.71 \\
$\mathrm{COOH}$ & NI & NI & NI & NI & NI & NI & 500 & 1.86 \\
$\mathrm{SO}_{3}{ }^{-} \mathrm{Na}^{+}$ & NI & NI & NI & NI & NI & NI & NI \\
$\mathrm{NO}_{2}$ & 500 & 1.18 & NI & NI & 125 & 0.96 & 62.5 & NI \\
\hline
\end{tabular}

NI - no inhibition up to $500 \mu \mathrm{g} / \mathrm{mL}$. 
chemical shifts of the methine protons, which we have already discussed.

(ii) on $\mathbf{C}-\alpha$ : There is an acceptable correlation with the ${ }^{13} \mathrm{C}-\mathrm{NMR}$ chemical shifts of $\mathrm{C}-\alpha$. The plot of ${ }^{13} \mathrm{C}-\mathrm{NMR}$ chemical shifts of $\mathrm{C}-\alpha$ versus the Hammett constants gives an equation: $\delta \mathrm{C}-\alpha=(159.43 \pm 0.58)+(11.57 \pm 1.82) \sigma_{\mathrm{p}}$, where the value of the Hammett reaction constant $\rho=$ +11.57 with a correlation coefficient of 0.9047 and standard deviation of 1.84 for $n=11$. We suggest that the 4'-substituents perturb the aldimine $\pi$-bond. This is corroborated by the multiple linear regression which considers the inductive $\left(\sigma_{\mathrm{I}}\right)$ and resonance $\left(\sigma_{\mathrm{R}}\right)$ dual parameters, and the chemical shifts for ${ }^{13} \mathrm{C}-\alpha$, where a major contribution of the $\sigma_{R}$ parameter is demonstrated.

$$
\begin{aligned}
& \delta \mathrm{C}-\alpha=(9.56 \pm 2.73) \sigma_{\mathrm{I}}+(11.36 \pm 2.48) \sigma_{\mathrm{R}}+ \\
& \mathrm{n}=11 \\
& \text { correlation coefficient }(\mathrm{r})=0.904 \\
& \text { standard deviation }(\mathrm{s})=1.953
\end{aligned}
$$

The comparison of the relationships concerning $\delta \mathrm{C}-\alpha$ with other results in the literature indicated similar chemical shifts considering the electronic effects. The substituted N-benzylidenanilines 9 showed an acceptable Hammett correlation with $\rho=4.06$ (correlation coeficient $=0.922$ ) and the ${ }^{13} \mathrm{C}$-NMR shifts of C- $\alpha$ were more largely affected in the piperonal Schiff base series $(\rho=11.57)$, than those reported ${ }^{9}$.

(iii) on C-1': The conventional effects of electron-withdrawing and electron-releasing groups were observed. There is a poor Hammett correlation with a correlation coefficient of 0.8670 for the equation

$\delta \mathrm{C}-1^{\prime}=(150.46 \pm 1.05)+(17.03 \pm 3.26) \sigma_{\mathrm{p}}$ and $\mathrm{n}=11 ;$ $\mathrm{sd}=3.30$. In this case the multiple linear regression considering $\sigma_{I}$ and $\sigma_{R}$ parameters, also showed the major dependence on the resonance effect and a better correlation.

$$
\begin{aligned}
& \delta C^{\prime}-1^{\prime}=(10.77 \pm 2.44) \sigma_{I}+(21.60 \pm 2.21) \sigma_{R}+ \\
& (151.54 \pm 0.85) \\
& n=11 \\
& r=0.969 \\
& s d=1.745
\end{aligned}
$$

As an example, for the compound without a 4'-substituent, the chemical shift is $151.82 \mathrm{ppm}$, whereas with the 4'-nitro group the chemical shift is $163.64 \mathrm{ppm}$ and with a 4'-methoxyl group, the chemical shift is $144.77 \mathrm{ppm}$ (other values are cited in Table 1).

(iv) on C-4': The results obtained are noteworthy. It is clear that groups which are linked by atoms which are obviously more electronegative produce chemical shifts in the expected direction, that is, values at low field are observed when compared with that with 4'-hydrogen (125.48 ppm). However, even the methyl group produces a considerable low field shift (135.23 ppm).

We associate this with the following structural feature. The imidoyl nitrogen is a strong electron-donor to the ring to which it is directly attached and this must inter alia increase markedly the electron-density on C-4'. This induces a perturbation towards the methyl group due to its polarizability, as compared with the hydrogen linked to C-4'.

The heavy halogens joined to C-4' are a special case. Their p-electrons cause a shielding in the order $\mathrm{I}>\mathrm{Br}>\mathrm{Cl}$. This more than counteracts the electronegativity effect with $\mathrm{I}$ and $\mathrm{Br}$ and approximately cancels the electronegativity effect in the case of $\mathrm{Cl}$. Thus, the $\mathrm{C}-4$ ' chemical shifts are at high field for 4'-iodo (89.71 ppm) and 4'-bromo (118.83 ppm) and practically unchanged for the 4'-chloro compound (130.74 ppm). These values, $\delta \mathrm{C}-4$ ', were compared with the corresponding substituted N-benzylidenanilines $^{9,19}$ showing small changes except for the 4-chloro derivative.

As shown in Table 3, the Schiff Bases were tested against the filamentous fungi, all dermatophytes. Most of the Schiff Bases were found to possess good activity, and especially against Epidermophyton floccosum, for which the most active compounds were 4' $-\mathrm{Br}, \mathrm{Cl}, \mathrm{C}_{2} \mathrm{H}_{5}, \mathrm{NO}_{2}$ and $\mathrm{OCH}_{3}$ with MCI values ca. $2 \times 10^{-4} \mathrm{M}$. The assays with bacteria and yeasts showed that the Schiff Bases were inactive.

A good correlation was not obtained between the biological activity values (MCI, $1 / \mathrm{MCI}$ or $\log 1 / \mathrm{MCI}$ ) and substituent constants $\left(\sigma_{\mathrm{p}}, \sigma_{\mathrm{R}}\right.$ and $\left.\sigma_{\mathrm{I}}\right)$ indicating that electronic effects have no significant contribution in these results. This indicates that an evaluation of lipophilic parameters is important for a better understanding between bilological activity and chemical structure relationships.

\section{Acknowledgments}

The authors are grateful to CNPq and CAPES for financial support.

\section{References}

1. Patai, S. The Chemistry of the $C=N$ Bond; Patai, S., ed.; Interscience Publishers, New York, London, 1970, Chapter 1.

2. Brady, O.L.; Miller, J. J. Chem. Soc. 1950, 1234; ibid. 1953, 4076.

3. Miller, J. J. Amer. Chem. Soc. 1954, 76, 448; Miller, J. Aust. J. Chem. 1956, 2, 61.

4. Bayliss, N.S.; Little, H.L.; Heppolette, R.L.; Miller, J. J. Amer. Chem. Soc. 1956, 78, 3375.

5. Miller, J.; Parker, A.J.; Bolto, B.A. J. Amer. Chem Soc. 1957, 79, 93. 
6. Miller, J.; Parker, A.J. Aust. J. Chem. 1957, 11, 302.

7. Freire, H.R.; Miller, J. J. Chem. Soc. Perkin Trans. II 1978, 108.

8. Camargo, F.A.; Freire, H.R.; Echevarria, A.; Miller, J.; Nascimento, M.G. Abstract of Papers, $3^{\text {rd }}$ Int. Conf. Mech. Reactions in Solution, Canterbury, 1982, Abstracts p. 13.

9. Echevarria, A.; Miller, J.; Nascimento, M.G. Magn. Reson. Chem. 1985, 23, 809.

10.Perry, B.F.; Beezer; A.E.; Miles, R.J.; Smith, B.V.; Miller, J.; Nascimento, M.G. Microbios 1986, 45, 181.

11. Carvalho, I.; Reis, M.L.; Curti, C.; Miller, J. Abstract of Papers, XVI Reunião Anual da SBBQ, Caxambu, 1987, Abstract F-2.
12. Miller, J.; Miyata, Y.; Teramoto, E.S. J. Chem. Res. 1986 (S), 355 (M), 3072.

13. Barbosa, R.C.; Echevarria, A.; Giesbrecht, A.M.; Geronimo, V.; Nascimento, M.G.; Young, M.C.M. Abstract of Papers, $38^{\mathrm{a}}$ Reunião Anual da SBPC, Ciência e Cultura (Supl.) 1986, 38, 584.

14. Takagi, K.; Kasuya, Y.; Fuji, K.; Watanabe, M.; Kayaoba, S. Chem. Pharm. Bull. 1963, 11, 654.

15. Baldessari, A.; Gros, E.G.Z. Naturforsch. 1983, 386, 997.

16. Bigelow, L.A.; Eatough, H. Org. Synth. Coll. I 1967, 80.

17. Martin, Y.M. Quantitative Drug Design - A Critical Introduction (Marcel Dekker), Inc., p. 376, 1978.

18. Charton, M. Prog. Phys. Org. Chem. 1991, 119.

19. Tabei, S.; Saitou, E. Bull. Chem. Soc. Jpn. 1969, 1440.

Received: July 15, 1997

FAPESP helped in meeting the publication costs of this article 